\title{
KELIO TIESIAMŲJŲ RAUMENŲ JĖGOS SVYRAVIMO PRIKLAUSOMYBE் NUO HIPERTERMIJOS ATLIEKANT MAKSIMALAUS INTENSYVUMO IZOMETRINIUS PRATIMUS
}

\author{
Marius Brazaitis, Albertas Skurvydas, Kazimieras Pukẻnas, Kazys Vadopalas, \\ Ieva Lukošiūtè-Stanikūnienė, Nerijus Masiulis, Sigitas Kamandulis \\ Lietuvos kūno kultūros akademija, Kaunas, Lietuva
}

\begin{abstract}
Marius Brazaitis. Lietuvos kūno kultūros akademijos biomedicinos krypties doktorantas. Mokslinių tyrimų kryptis — raumenų fiziologija: temperatūros poveikis raumenų funkcijai.
\end{abstract}

\begin{abstract}
SANTRAUKA
Tyrimo tikslas - nustatyti kelio tiesiamuju raumenujejgos svyravimo priklausomybę nuo hipertermijos atliekant maksimalaus intensyvumo izometrinius pratimus. Tiriamieji - sveiki fiziškai aktyvūs vyrai $(n=9)$ (amžius - 21,6 $\pm 2,6$ m.,

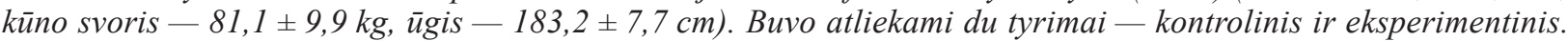
Eksperimentinis nuo kontrolinio skyrèsi tuo, kad jo metu kojos buvo šildomos pasyviai (tiriamieji 45 min kojas laikè šiltoje vonioje, kurios vandens temperatūra $-44 \pm 1{ }^{\circ} \mathrm{C}$ ). Visi tiriamieji atliko $80 \mathrm{~s}$ valinga izometrini krūvi, tiesdami koja per kelio sqnari fiksuotu $120^{\circ}$ kampu (naudotas izokinetinis dinamometras). Registruota keturgalvio šlaunies raumens maksimalioji valinga jëga (MVJ). Rektalinè temperatūra buvo matuojama prieš pasyvu koju šildyma ir po jo. Raumenu susitraukimo jejgos svyravimas juvertintas spektro galios tanki (SGT) skaičiuojant pagal Welsh.
\end{abstract}

Po pasyvaus koju šildymo rektalinè temperatūra padidèjo nuo 37,35 $\pm 0,32$ iki 39,31 $\pm 0,31^{\circ} \mathrm{C}(p<0,001 ; p<0,05)$. Kontrolinio ir eksperimentinio tyrimo metu trečia krūvio sekundę MVJ sumažèjo, lyginant su prieš krūvỉ nustatyta reikšme, ir šis reikšmingas pokytis išliko 15 s po krūvio $(p<0,05)$. Dešimta izometrinio krūvio sekunde nustatytas reikšmingas MVJ skirtumas tarp kontrolinio ir eksperimentinio tyrimo rodikliu $(p<0,05)$. Dvieju veiksniu dispersi$n e$ analizé parodè, kad analizuojamu jègos rodikliu pokytis priklauso nuo laiko $(p<0,001)$ ir hipertermijos dydžio $(p<0,01)$, o sqveikos tarp ju rodikliai reikšmingai nepakito $(p>0,05)$. Išanalizavus viso krūvio pradžios ir pabaigos nuovargio indeksq (NI) pastebèta, kad hipertermija reikšmingai labiau padidino nuovargio rodikli $(p<0,05)$, palyginti su kontroline reikšme. Laikas reikšmingai paveikè jẻgos svyravimo SGT dydžio ir dažnio juostos (DJ) kaita $(p<0,001)$, o hipertermija vertinamu rodikliu nepaveike $(p>0,05)$. Hipertermija (eksperimentinis tyrimas) padidino raumenu nuovargi, bet nepakeitè jëgos svyravimo (dažnio ir amplitudès) kaitos sudètingumo atliekant maksimalaus intensyvumo izometrini krūvi. Eksperimentinio ir kontrolinio tyrimo metu spektro galios tankio amplitudès ir dažnio juostos rodikliai pakito vienodai. Jègos signalo spektro galios tankio rodikliu kaita sudètingeja priklausomai nuo laiko, t. y. kuo ilgiau atliekamas pratimas, tuo jègos svyravimas darosi sudètingesnis ir mažiau prognozuojamas (išsiplečia dažniujuosta, atsiranda keli dominuojantys dažniai).

Raktažodžiai: hipertermija, raumenujègos svyravimas, izometriniai pratimai, spektriné analizé.

\section{IVADAS}

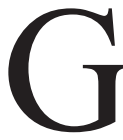
riaučių raumenu veikla stipriai koreliuoja su temperatūros pokyčiais juose (Bennett, 1984; Ranatunga, 1998; De Ruiter, De Haan, 2000). Padidejjus ašinei kūno temperatūrai iki kritinès ribos (vidutinio fizinio aktyvumo asmenu $-38,7 \pm 0,2^{\circ} \mathrm{C}$, didelio meistriškumo $\left.-39,2 \pm 0,1^{\circ} \mathrm{C}\right)$, žmogaus kūnas perkaista, atsiranda nuovargis, o hidratacija ir aklimatizacija šio pokyčio neveikia (Cheung, McLellan, 1998). Hipertermija padidina fiziologinę kūno įtampa, dèl kurios gali smarkiai sumažèti fizinis darbingumas, padidèja viso kūno išsekimo, perkaitimo, traumos ar netgi mirties tikimybè. Daugelis gyvūnų nutraukia fizinę veiklą tada, kai jų ašinè kūno temperatūra pasiekia saugią ribą. Literatūroje nuolatos keliama hipotezè, kad pavojingai aukšta vidinè kūno temperatūra tiesiogiai padidina nuovargị ir pagreitina išsekimą. Pastaroji tema plačiai nagrinejjama, tačiau esminiai mechanizmai iki galo nèra išsiaiškinti (Morrison et al., 2004). Hiperter- 
mijos sąlygomis fizinis darbingumas sumažèja dèl ašinès temperatūros padidèjimo iki kritinès ribos (Cheung, McLellan, 1998), kurią pasiekus yra aktyvinamos termoreguliacijos ir širdies kraujagysliu sistemos (Rowell, 1974). Hipertermijos sąlygomis atsiradę periferijos pokyčiai - padideję̨s raumenu susitraukimo ir atsipalaidavimo greitis (De Ruiter, De Haan, 2000) - gali tiesiogiai paveikti raumenų valingą aktyvavimą, nes temperatūra pakeičia motorinio vieneto impulso dažni, reikalingą tetaniniam susitraukimui atlikti (Todd et al., 2004).

Jègos svyravimo rodiklis yra svarbus indikatorius vertinant neuroraumeninę sistemą (Newell, Corcos, 1993; Hausdorff et al., 1994). Manoma, kad raumenų jègos svyravimas glaudžiai susijęs su motorinių vienetų jaudinimo struktūros persitvarkymu. Daugelis tyrimu parodè, kad jëgos svyravimo mechanizmas priklauso nuo impulso dažnio motoriniame vienete dydžio (Allum et al., 1978; Christakos, 1982), jo kaitos (Enoka et al., 2003) ir sinchroniškumo tarp jų (Taylor et al., 2002). Atlikta nemažai tyrimų, vertinant širdies kraujagyslių sistemos ritmiškumą, jègos svyravimą ir priklausomumą nuo amžiaus ir ligos, tačiau nepavyko rasti tokiu (Christou, Carlton, 2002; Kornatz et al., 2005), kurie nagrinètuc, kaip hipertermija veikia jègos svyravimą.

Tyrimo tikslas - nustatyti kelio tiesiamujų raumenu jègos svyravimo priklausomybę nuo hipertermijos atliekant maksimalaus intensyvumo izometrinius pratimus.

\section{TYRIMO METODAI IR ORGANIZAVIMAS}

Tiriamieji - sveiki fiziškai aktyvūs vyrai $(\mathrm{n}=9)$. Jų amžius — 21,6 $\pm 2,6$ m., kūno svoris $81,1 \pm 9,9 \mathrm{~kg}$, ūgis $-183,2 \pm 7,7 \mathrm{~cm}$. Tiriamieji buvo supažindinti su tyrimo tikslais, procedūra ir galimais nepatogumais. Norą dalyvauti tyrime jie patvirtino raštu. Tyrimas atliktas laikantis $1975 \mathrm{~m}$. Helsinkio deklaracijoje priimtų principų dèl eksperimentu su žmonèmis etikos. Tyrimo protokolas aptartas ir patvirtintas Kauno regioniniame biomedicininių tyrimų etikos komitete (Protokolo Nr. 130/2005; Leidimo Nr. BE-2-54).

Dinamometro nustatymas. Izometrinè kelio tiesiamujų raumenų jèga buvo vertinama naudojant izokinetini dinamometrą (Biodex Medical System 3, New York). Tiriamieji sodinami i dinamometro įrenginio kẻdę, testuojama dešinè koja. Prie dinamometro pritvirtinamas papildomas blauzdos tvirtinimo itaisas. Nustatoma kelio anatominè są- nario ašis ir sulyginama su dinamometro dinaminès apkrovos mazgo ašimi. Nustatoma visa kelio sąnario amplitude (ištiesus koją $0^{\circ}$ ir sulenkus $115^{\circ} \mathrm{kampu}$ ). Norint sumažinti viso kūno inercini svyravimą, tiriamasis apjuosiamas pečių, liemens ir šlaunies diržais. Blauzda sutvirtinama diržu su sagtimi virš kulnakaulio gumburo ties apatiniu trečdaliu, koja per kelio sąnari fiksuojama 90 ir $60^{\circ} \mathrm{kampu}$, pasveriama tada, kai ji fiksuota $72 \pm 5^{\circ}$ kampu (gravitacinès sunkio jègos momentu).

Eksperimento aprašymas. Buvo atliekami du tyrimai - kontrolinis ir eksperimentinis. Eksperimentinis nuo kontrolinio skyrèsi tuo, kad jo metu kojos buvo šildomos pasyviai.

Prieš eksperimentą atliktas žvalgomasis tyrimas, kurio metu tiriamieji turèjo priprasti prie laboratorijos aplinkos sąlygų ir pasimokyti atlikti maksimaliai valingą (MVJ) izometrini krūvị. Ne anksčiau kaip po savaitès tiriamieji kontrolinio arba eksperimentinio tyrimo metu atliko krūvị.

Taikant pasyvaus šildymo metodiką, tiriamieji, atvykę i laboratoriją, $30 \mathrm{~min}$ ramiai sèdèdavo iprastinès temperatūros kambaryje $\left(20-22{ }^{\circ} \mathrm{C}\right)$ (Sargeant, 1987), išmatuota jų rektalinè temperatūra. Vèliau buvo atliekamas kontrolinis MVJ matavimas, t. y. darant 2 min pertrauką atlikti trys maksimalūs valingi raumens susitraukimai tiesiant blauzdą per kelio sąnari $120^{\circ}$ fiksuotu kampu (raumens susitraukimo trukmè $-5 \mathrm{~s}$ ). Paskui buvo taikomas pasyvus kojų šildymas, iš karto po šildymo vèl matuojama rektalinè temperatūra. Išlipus iš vonios, ne vèliau kaip po $5 \mathrm{~min}$, tiriamasis buvo sodinamas i specialią dinamometro kẻdę ir turèjo atlikti MVJ izometrinį krūvị. Praejjus 15 (A 15) ir 300 (A 300) s po krūvio, atliekamas kontrolinis testavimas.

Kontrolinio tyrimo metu po neintensyvios pramankštos (10 min bègimo - pulso dažnis 110 $130 \mathrm{tv}$ / min) tiriamieji buvo sodinami ị specialią izokinetinio dinamometro kèdę ir atliko testavima pagal tą pati protokola kaip ir eksperimentinio tyrimo metu, tik pasyviai kojų nešildant ir nematuojant rektalinès temperatūros.

MVJ izometrinis krūvis. MVJ izometrinis krūvis truko $80 \mathrm{~s}$. Tiriamieji krūvio metu buvo motyvuojami verbaliniu ir vizualiu jègos signalo kitimo atgaliniu ryšiu. Tiriamasis maksimaliomis pastangomis turejo tiesti koją per kelio sąnarį $120^{\circ}$ fiksuotu kampu (rankos sukryžiuotos ant krūtinès). Registruota keturgalvio šlaunies raumens maksimalioji valinga jèga.

Pasyvaus šildymo metodika. Tiriamieji 45 min sèdèjo kojas panardinę šiltoje vonioje, 
kurios vandens temperatūra $-44 \pm 1{ }^{\circ} \mathrm{C}$, kambario temperatūra $20-22^{\circ} \mathrm{C}$. Šildymo metu jie negalèjo vartoti jokių gèrimų ar naudoti dirbtinio vėsinimo įrenginių. Šildymo pabaigoje raumens temperatūra $3 \mathrm{~cm}$ gylyje padidèja $\sim 2,7^{\circ} \mathrm{C}$ (Sargeant, 1987; Ramanauskienè ir kt., 2006). Vandens temperatūra buvo matuojama buitiniu vandens termometru, patalpos - oro termometru.

Rektalinès temperatūros matavimo metodika. Pagrindinis hipertermijos būsenos nustatymo rodiklis yra rektalinè temperatūra (Cheung, McLellan, 1998). Rektalinè temperatūra buvo matuojama silikoninès gumos zondu su termodavikliu (Ellab, tipas Rectal probe, Danija). Tiriamasis prieš pasyvų šildymą ir po jo įsikišdavo zondą su termodavikliu i išeinamają angą (laikas - $10 \mathrm{~s}$, gylis $-12 \mathrm{~cm}$ ) (Proulx et al., 2003). Zondas su termodavikliu po panaudojimo buvo sterilizuojamas autoklave.

Spektro galios tankio (SGT) matavimas. MVJ izometrinio krūvio metu užregistruota jègos signalo laiko eilutè, diferencijuota taikant skirtumo funkciją, t. y. nustatant raumenų jègos svyravimus. Tyrimo metu užregistruotų svyravimų (registravimo dažnis - $100 \mathrm{~Hz}$ ) amplitudè ir dažnis parodè dinaminių sistemų sudètingumo kaitą. Laiko eilute buvo suskaidyta i aštuonias laiko imtis po 1000 taškų. SGT pagal Welch yra plačiai naudojamas rodiklis vertinant fiziologinius raumenu valingu susitraukimu procesus (Farina et al., 2002).

Matematinè statistika. Buvo apskaičiuojami rodiklių aritmetiniai vidurkiai ir standartiniai nuokrypiai. Vegetacinių sistemų rodiklių kaitos priklausomumas nuo raumenų temperatūros ir laiko kaitos buvo analizuojamas taikant dviejų veiks- nių dispersinę analizę. Skirtumo tarp aritmetinių vidurkiu reikšmingumas buvo nustatomas pagal Studento dvipusi nepriklausomų imčių $t$ kriterijų. Skirtumas statistiškai reikšmingas, kai $\mathrm{p}<0,05$.

\section{REZULTATAI}

Tyrimo metu nustatyta, kad po pasyvaus šildymo rektalinè temperatūra padidejjo nuo $37,35 \pm 0,32$ iki $39,31 \pm 0,31^{\circ} \mathrm{C}(\mathrm{p}<0,001)$.

Iš raumenu jègos kitimo maksimalaus intensyvumo izometrinio krūvio matyti (1 pav.), kad kontrolinio ir eksperimentinio tyrimo metu jèga 3 krūvio sekundę sumažèjo, lyginant su prieš krūvi nustatyta reikšme, ir šis reikšmingas pokytis išliko 15 s (A 15) po krūvio (p < 0,05). Lyginant kontrolinio ir eksperimentinio tyrimo rodiklius, dešimta krūvio sekundę nustatytas reikšmingas raumenų jègos skirtumas $(p<0,05)$. Dviejų veiksnių dispersinę analizè atskleide, kad analizuojamu jègos rodikliu pokytis priklausè nuo laiko $(\mathrm{p}<0,001)$ ir hipertermijos dydžio $(p<0,01)$, o sąveikos tarp jų rodikliai reikšmingai nepakito $(\mathrm{p}>0,05)$.

Išanalizavus viso krūvio pradžios ir pabaigos nuovargio indeksą (NI) pastebèta, kad hipertermija reikšmingai padidino vertinamą rodikli $(\mathrm{p}<0,05)$, palyginti su kontrolinio tyrimo reikšme ( 2 pav.).

Nustatyta, kad laikas reikšmingai paveike jègos svyravimo SGT dydžio ir dažnio juostos (DJ) kaitą $(\mathrm{p}<0,001)$ tada, kai hipertermija vertinamu rodiklių neveikè ( $p>0,05)$ (žr. 1 lent.). Didžiausias SGT dydis buvo nustatytas $0-10$ sekundę (kontrolinio tyrimo $-0,54 \pm 0,61 \mathrm{~N}^{2} / \mathrm{Hz}$, eksperimentinio $-0,59 \pm 0,53 \mathrm{~N}^{2} / \mathrm{Hz}$, šie dydžiai nustatyti atitinkamai $10,67 \pm 1,12-16,89 \pm 2,52 \mathrm{~Hz}$

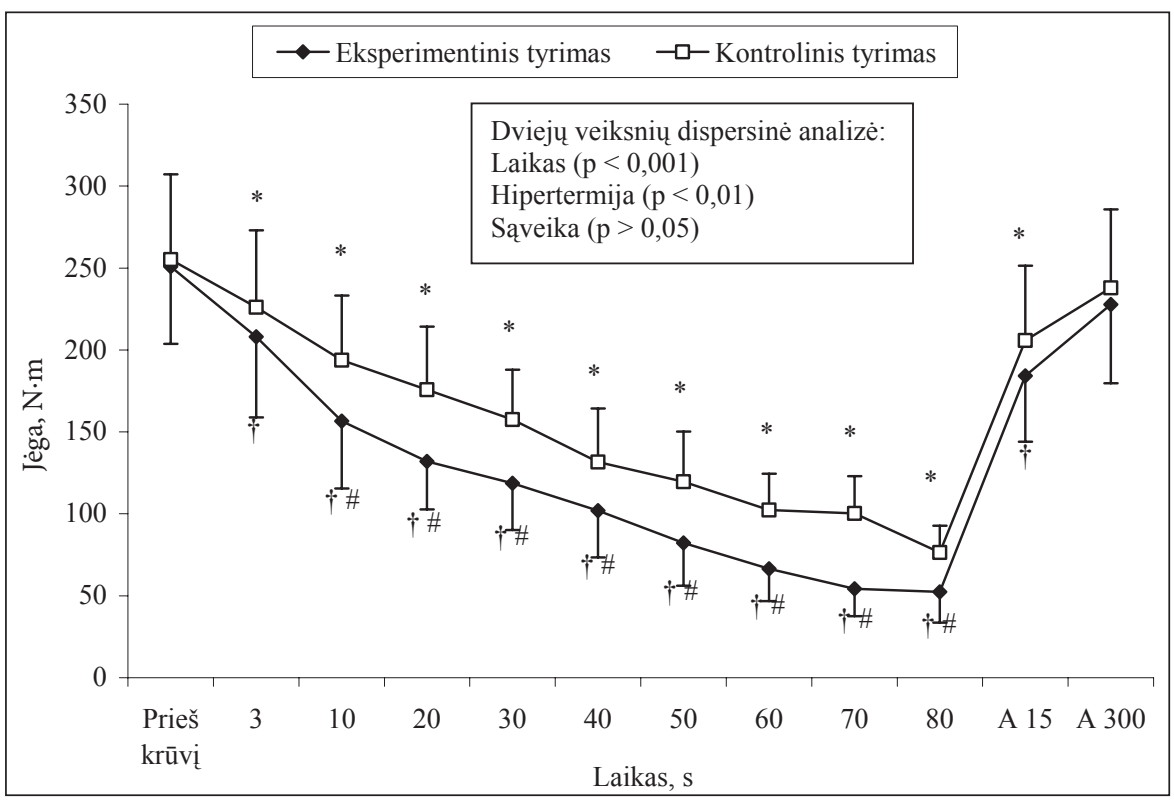

1 pav. MVJ rodikliai atliekant izometrinị krūvị, kai koja tiesiama $120^{\circ}$ fiksuotu kampu

Pastaba. \# - statistiškai reikšmingas skirtumas tarp kontrolinio ir eksperimentinio tyrimo rodiklių ( $\mathrm{p}<0,05$ ); $\dagger$ - eksperimentinio tyrimo rodikliai, palyginti su pradine reikšme $(\mathrm{p}<0,05)$; * - kontrolinio tyrimo rodikliai, palyginti su pradine reikšme $(\mathrm{p}<0,05)$. 
2 pav. MVJ nuovargio indeksas

Pastaba. \# - statistiškai reikšmingas skirtumas tarp kontrolinio ir eksperimentinio tyrimo rodiklių $(\mathrm{p}<0,05)$.

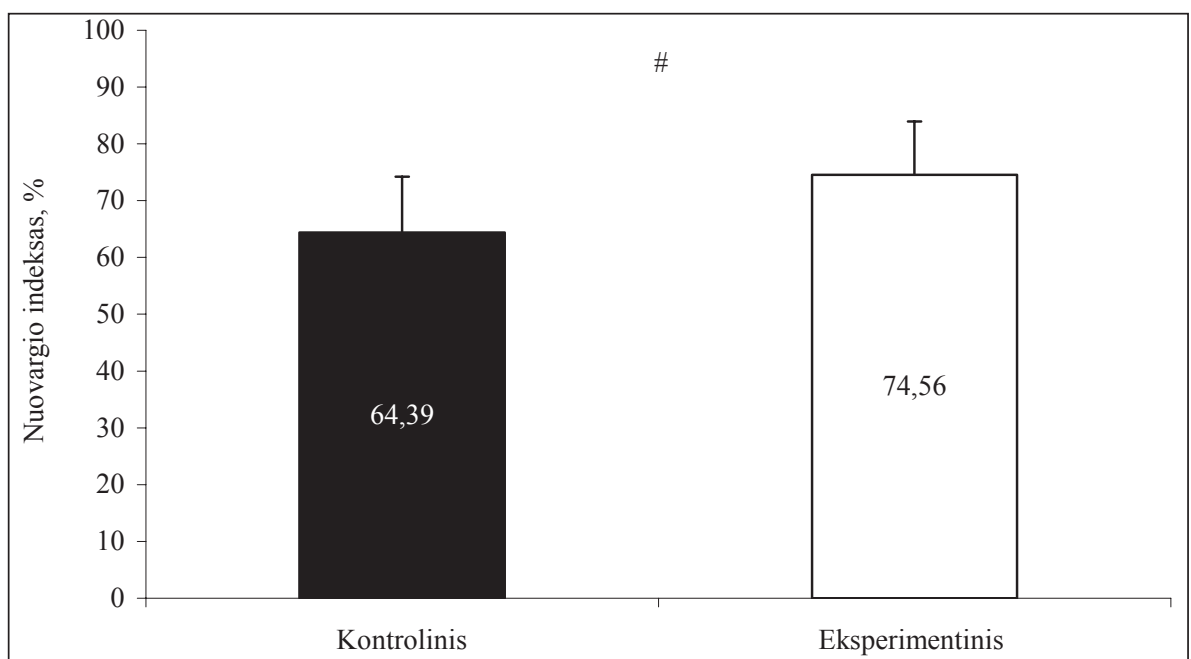

3 pav. Spektro galios tankio rodikliai atliekant MVJ izometrinị krūvị, kai koja tiesiama fiksuotu $120^{\circ}$ kampu (kontrolinis (A) ir eksperimentinis tyrimas (B))

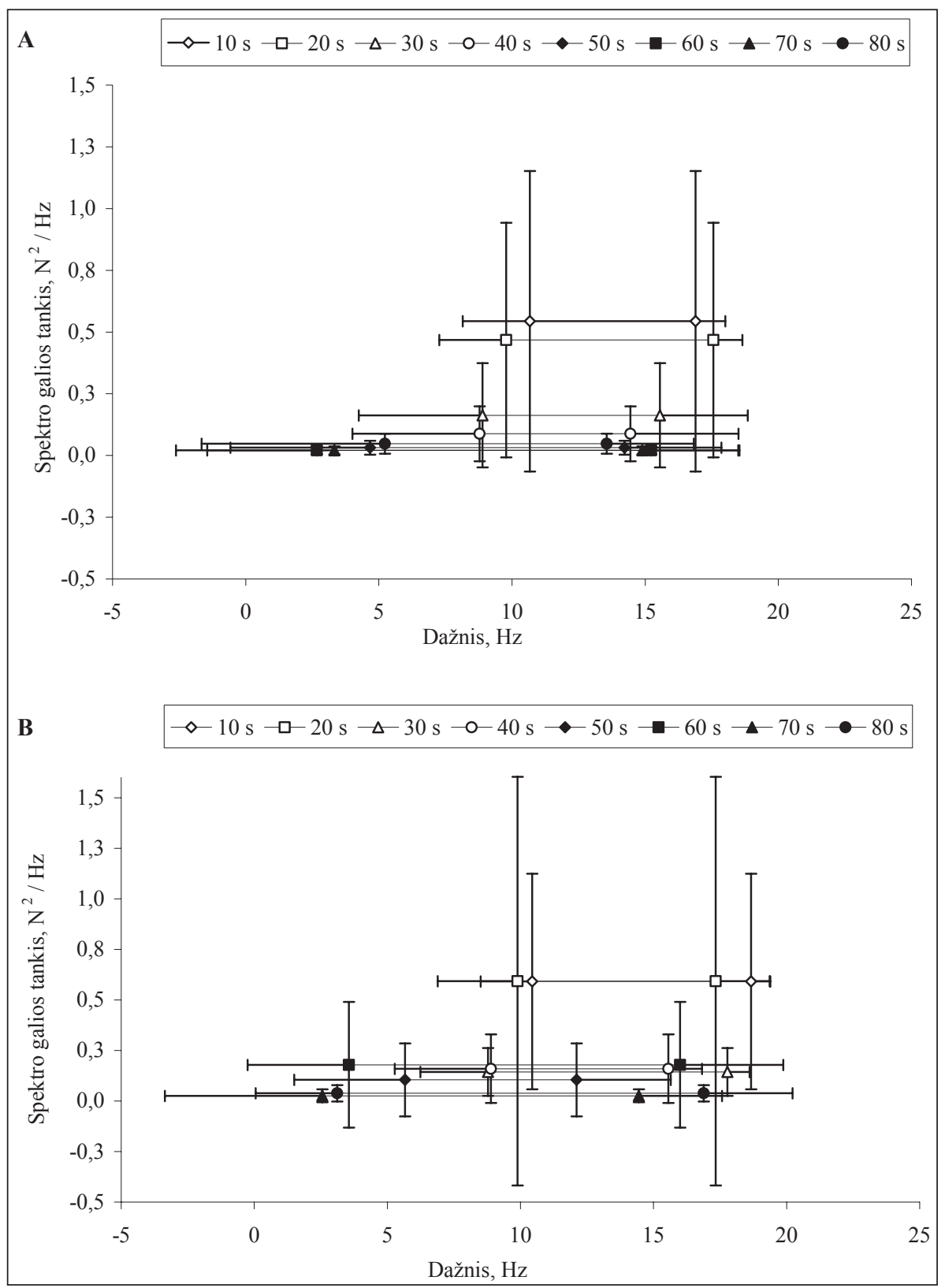

ir 10,44 \pm 0,73-18,67 $\pm 1,94 \mathrm{~Hz}$ dažnio juostoje), $\quad 0,03 \pm 0,03 \mathrm{~N}^{2} / \mathrm{Hz}$, kur dažnio juostos dydis — mažiausias - 60-70 sekundę (kontrolinio ty- $3,33 \pm 3,61-14,89 \pm 4,78 \mathrm{~Hz}$ ir 2,56 $\pm 3,13$ rimo $-0,02 \pm 0,02 \mathrm{~N}^{2} / \mathrm{Hz}$, eksperimentinio - 14,44 $\pm 5,92 \mathrm{~Hz}$ ) (3 pav.). 


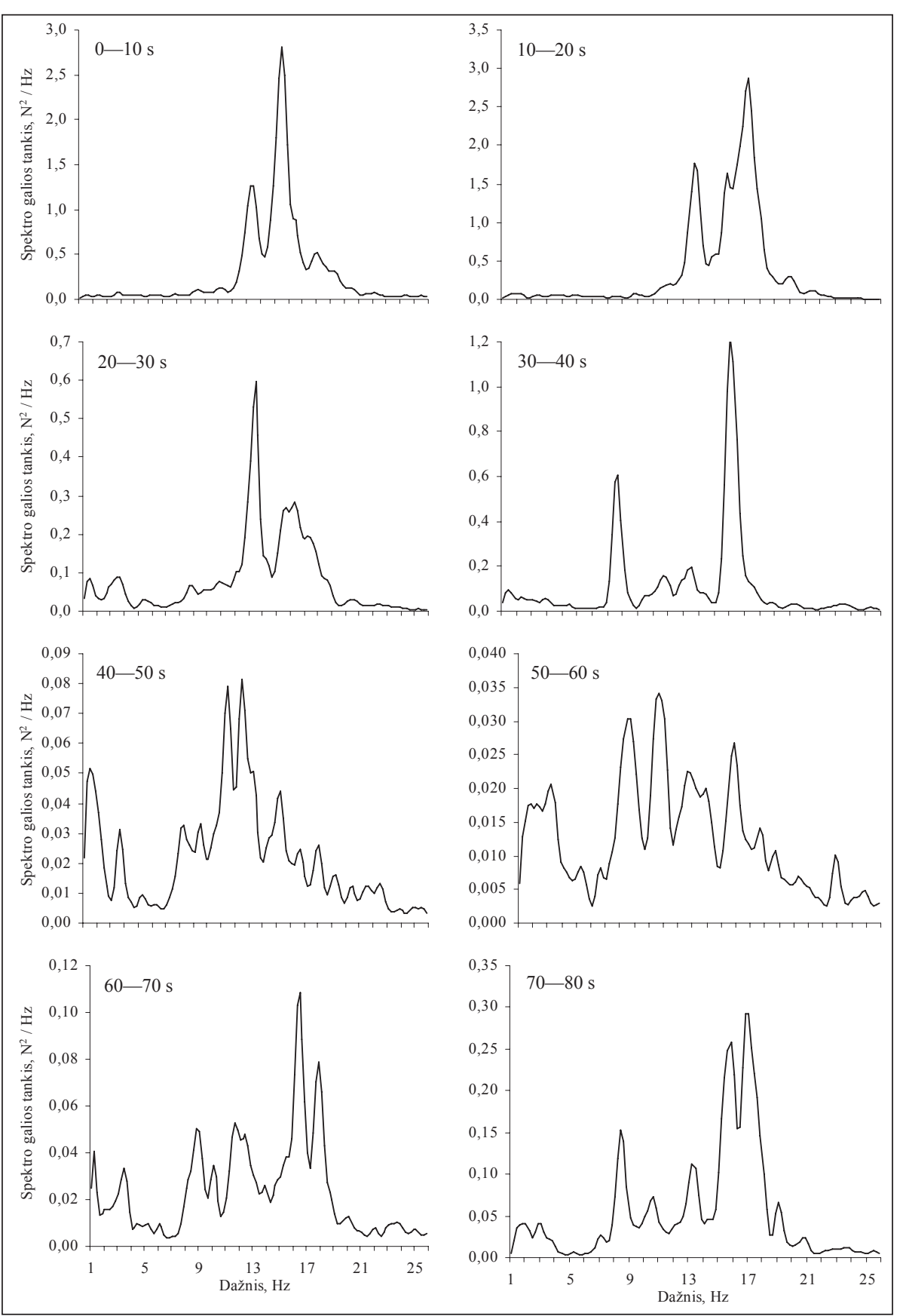

\begin{tabular}{|l|l|}
\hline Spektro galios tankio dydžio priklausomybe nuo: & $\mathrm{p}<0,001$ \\
Laiko & $\mathrm{p}>0,05$ \\
Hipertermijos & $\mathrm{p}>0,05$ \\
Sąveikos & \\
\hline Dominuojančio dažnio lauko dydžio priklausomybė nuo: & $\mathrm{p}<0,001$ \\
Laiko & $\mathrm{p}>0,05$ \\
Hipertermijos & $\mathrm{p}>0,05$ \\
Sąveikos & \\
\hline
\end{tabular}

4 pav. Spektro galios tankio rodikliai atliekant MVJ izometrini krūvị, kai koja tiesiama fiksuotu $120^{\circ} \mathrm{kampu}$ (originalūs vieno tiriamojo duomenys (kontrolinis tyrimas))

\section{REZULTATŲ APTARIMAS}

Šiuo tyrimu nustatyta: kojų pasyvaus šildymo metu padidejusi rektalinè temperatūra rodo tiriamujų hipertermiją.
A. J. Sargeant (1987) nustaté, kad pasyviai šildant kojas vandenyje vidinè raumenu ( $3 \mathrm{~cm}$ gylyje) temperatūra padideja $\sim 2,7^{\circ} \mathrm{C}$, o vienkartinio raumens susitraukimo jèga ir galingumas apytikriai padidejja $11 \%$, tačiau dèl to greičiau atsiranda 
nuovargis. I. Ramanauskienès ir kt. (2006) atliktu tyrimu nustatyta raumenų vidinè temperatūra buvo tokia pati, o raumenų susitraukimo jejga ir galingumas, atliekant izokinetinius pratimus (50 kojos tiesimu—-lenkimu) dideliu greičiu $\left(450^{\circ} / \mathrm{s}\right)$, išliko nepakitusi, palyginti su pradinėmis reikšmėmis.

Padidèjus ašinei kūno temperatūrai iki $38,7^{\circ} \mathrm{C}$ (vidutinio fizinio aktyvumo asmenu) ar iki $39,2^{\circ} \mathrm{C}$ (didelio meistriškumo), kūnas perkaista, atsiranda nuovargis (Cheung, McLellan, 1998). Pasyviai padidinus ašinę kūno temperatūrą iki $39,5^{\circ} \mathrm{C}$ ir atliekant $10 \mathrm{~s}$ trukmès maksimalaus intensyvumo izometrinius pratimus (kojos tiesimą $120^{\circ}$ fiksuotu kampu), raumenų jèga sumažèja $11 \pm 13 \%$, palyginti su pradinėmis reikšmèmis (Morrison et al., 2004). Atlikto tyrimo metu tiriamuju ašinè temperatūra padidejo iki $39,3 \pm 0,3^{\circ} \mathrm{C}$, o raumenu jèga buvo $14 \pm 5,7 \%$ mažesne, taip pat nustatytas greitesnis raumenu nuovargis, lyginant su pradinėmis reikšmėmis. Manoma, kad centrinès nervu sistemos nuovargis tiesiogiai priklauso nuo ašinès temperatūros padidèjimo, pastaroji priklausomybè ir yra pagrindinis indikatorius, kuris lemia greitesni raumenu jègos mažèjimą dirbant izometriniu režimu ir lyginant su pradinèmis reikšmėmis (Morrison et al., 2004).

Tyrimo metu pastebèta, kad hipertermija nepadidino kojos tiesiamuju raumenų maksimaliosios jègos rodikliu kaitos atliekant izometrinius pratimus. Vertinant SGT ir DJ kaitą valingo izometri- nio krūvio metu nustatyta, kad didejjant raumenu nuovargiui jëgos svyravimų dominuojančios amplitudès dydis mažėjo, o dažnio juosta išsiplètè. Išsiplètus dažnio juostai, padidejo panašaus dydžio amplitudžių skaičius, kuris rodo maksimaliosios raumenų jègos fiziologinių rodiklių (motorinių vienetu suminès impulsacijos ir sinchroniškumo dažnio) kaitos sudètingumą (4 pav.). Apibendrinant tyrimo rezultatus galima teigti, kad jègos svyravimo rodikliai kinta priklausomai nuo laiko, ir tai daugiau lemia raumenų nuovargio mechanizmai, o ne hipertermija.

\section{IŠVADOS}

1. Hipertermija (eksperimentinis tyrimas) padidino raumenų nuovargi, bet nepakeite jègos svyravimo (dažnio ir amplitudès) kaitos sudètingumo atliekant maksimalaus intensyvumo izometrini krūvị.

2. Eksperimentinio ir kontrolinio tyrimų metu spektro galios tankio amplitudès ir dažnio juostos rodikliai pakito vienodai.

3. Jègos signalo spektro galios tankio rodiklių kaita sudètingeja priklausomai nuo laiko, t. y. kuo ilgiau atliekamas pratimas, tuo jègos rodikliu svyravimas darosi sudètingesnis ir mažiau prognozuojamas (išsiplečia dažnių juosta, atsiranda keli dominuojantys dažniai).

\section{LITERATŪRA}

Allum, J. H. J., Dietz, V., Freund, H. (1978). Neuronal mechanisms underlying physiological tremor. Journal of Neurophysiology, 41, 557-571.

Bennett, A. F. (1984). Thermal dependence of muscle function. American Journal of Physiology, 247, R 217-229.

Cheung, S. S., Mclellan, T. M. (1998). Comparison of short-term aerobic training and high aerobic power on tolerance to uncompensable heat stress. Aviation, Space, and Environmental Medicine, 70 (7), 637-643.

Christakos, C. N. (1982). A study of the muscle force waveform using a population stochastic model of skeletal muscle. Biology of Cybernetic, 44, 91-106.

Christou, E. A., Carlton, L. G. (2002). Age and contraction type influence motor output variability in rapid discrete tasks. Journal of Applied Physiology, 93, 489-498.

Enoka, R. M., Christou, E. A., Hunter, S. K. et al. (2003). Mechanisms that contribute to differences in motor performance between young and old adults. Journal of Electromyography Kinesiology, 13, 1-12.

Farina, D., Fattorini, L., Felici, F., Filligoi, G. (2002). Nonlinear surface EMG analysis to detect changes of motor unit conduction velocity and synchronization. Journal of Applied Physiology, 93, 1753-1763.

Hausdorff, J. M., Peng, C. K., Ladin, Z., Wei, J. Y., Goldberger, A. L. (1994). Is walking a random walk? Evidence for long-range correlations in stride interval of human gait. Journal of Applied Physiology, 78, 349-358.

Kornatz, K. W., Christou, E. A., Enoka, R. M. (2005). Practice reduces motor unit discharge variability in a hand muscle and improves manual dexterity in old adults. Journal of Applied Physiology, 98, 2072-2080.

Morrison, S., Sleivert, G. G., Cheung, S. S. (2004). Passive hyperthermia reduces voluntary activation and isometric force production. European Journal of Applied Physiology, 91, 729-736.

Newell, K. M., Corcos, D. M. (1993). Variability and motor control. Champaign, IL: Human Kinetics.

Proulx, C. I., Ducharme, M. B., Kenny, G. P. (2003). Effect of water temperature on cooling efficiency during Hyperthermia in humans. Journal of Applied Physiology, 94, 1317-1323.

Ramanauskienè, I., Skurvydas, A., Brazaitis, M. ir kt. (2006). Moterų ir vyrų kelio tiesiamujų ir lenkiamujų raumenų susitraukimo funkcijos priklausomybè nuo tempera- 
tūros. Ugdymas. Kūno kultūra. Sportas, 3 (63), 49—54.

Ranatunga, K. W. (1998). Temperature dependence of mechanical power output in mammalian (rat) skeletal muscle. Experimental Physiology, 83, 371-376.

Rowell, L. B. (1974). Human cardiovascular adjustments to exercise and thermal stress. Physiological Review, 54, $75-159$.

De Ruiter, C. J., De Haan, A. (2000). Temperature effect on the force / velocity relationship of the fresh and fatigued human adductor pollicis muscle. European Journal of Physiology, 440, 163-170.
Sargeant, A. J. (1987). Effect of muscle on leg extension force and short-term power output in humans. European Journal of Applied Physiology, 56, 693-698.

Taylor, A. M., Steege, J. W., Enoka, R. M. (2002). Motorunit synchronization alters spike-triggered average force in simulated contractions. Journal of Neurophysiology, $88,265-276$.

Tood, G., Butler, J. E., Taylor, J. L., Gandevia, S. C. (2004). Hyperthermia: a failure of the motor cortex and the muscle. Journal of Physiology, 563 (2), 621-631.

\title{
DEPENDENCE OF KNEE EXTENSORS POWER FLUCTUATION ON HYPERTHERMIA PERFORMING ISOMETRIC EXERCISES AT MAXIMAL INTENSITY
}

\author{
Marius Brazaitis, Albertas Skurvydas, Kazimieras Pukẻnas, Kazys Vadopalas, \\ Ieva Lukošiūtė-Stanikūnienè, Nerijus Masiulis, Sigitas Kamandulis \\ Lithuanian Academy of Physical Education, Kaunas, Lithuania
}

\begin{abstract}
The aim of the research was to determine knee extensors isometric contraction power vibration stability fluctuation dependence on hyperthermia. The object of the study were healthy men who were physically active $(\mathrm{n}=9)($ age $-21.6 \pm 2.6$ years, weight $-81.1 \pm 9.9 \mathrm{~kg}$, height $-183.2 \pm 7.7 \mathrm{~cm})$. Two tests were carried out. The first one was control, the other was experimental. The experimental test differed from the control one in passive warming of legs (the participants of the test were keeping their legs in a warm bath for 45 minutes; the temperature of the water was $44 \pm 1^{\circ} \mathrm{C}$ ). All the participants experienced a voluntary isometric strain of 80 seconds when stretching one of their legs by a knee joint at a $120^{\circ}$ fixed angle (isokinetic dynamometer). The moment of maximum power was registered $(\mathrm{N} \cdot \mathrm{m})$. Rectal temperatures were measured before and after the passive heating. In order to evaluate the muscle isometric contraction power vibration stability fluctuation power spectrum density (PSD) was measured.

Rectal temperature increased from $37.35 \pm 0.32$ to $39.31 \pm 0.31^{\circ} \mathrm{C}(\mathrm{p}<0.001)$. The moment of muscle isometric contraction power decreased at the $3 \mathrm{rd}$ second of the strain. This significant change lasted for almost 15 seconds after the strain $(\mathrm{p}<0.05)$. A significant difference of muscle isometric contraction power between the hyperthermia and the control test was determined at the 10th second of the strain $(\mathrm{p}<0.05)$. When evaluating the dispersive analysis of the two factors, it was found that the change of the tested indices of the power depended on the factor of time $(p<0.001)$ and hyperthermia $(p<0.01)$ whereas the interaction between them did not bring a big influence on the results $(\mathrm{p}=0.564)$. The time influenced the value of power spectrum density (PSD) and the change of frequency rate (FR) $(p<0.001)$, whereas the time did not influence the indices judged as hyperthermia $(\mathrm{p}>0.05)$.

The results showed that hyperthermia impaired muscle fatigue, but did not change force output complexity during MVC isometric bout. Power spectrum density analyses showed similar shift of force output frequency and amplitude during the control and the experimental test. The level of force output complexity depended on the duration of exercise (more sustained exercise showed higher complexity level).
\end{abstract}

Keywords: hyperthermia, muscle vibration, isometric contraction of a muscle, spectrum analyses.

Gauta 2007 m. vasario 7 d.

Received on February 7, 2007

Priimta $2007 \mathrm{~m}$. balandžio $24 \mathrm{~d}$

Accepted on April 24, 2007
Marius Brazaitis

Lietuvos kūno kultūros akademija

(Lithuanian Academy of Physical Education)

Sporto g. 6, LT-44221 Kaunas

Lietuva (Lithuania)

Tel +370 37302677

E-mailkku712@yahoo.com 